\title{
Starting with the Self, Starting with Jackie \\ The Enduring Memory of Jackie Kirk \\ in our Practices of Reflexivity
}

\author{
Stephen Peters
}

\section{$\cos 80$}

This piece was written shortly after Jackie Kirk's death. At that time, I was a student in a Master's course on Women, Education and Development at McGill University. I am now about to begin my PhD at McGill University.

In September of 2008, I returned to the university classroom (as a first year Master's student) three years after completing my B.Ed at the University of Alberta. My first class that fall was Women, Education, and Development with Claudia Mitchell, Jackie Kirk's close friend and colleague. Jackie and Claudia had intended co-teaching the course. Sadly, we lost Jackie before that could happen. It was with great courage, in spite of her sense of loss and profound disappointment that Claudia, nevertheless, continued with the course, dedicating it to Jackie's memory and bringing Jackie to us as students through her words-as Jackie had left them in journals and research papers - and through the impression Jackie had made on her, Claudia, and the community more broadly. Having moved to Montreal that fall, I never had the opportunity to meet Jackie, but I feel that I met her through this course. Through her scholarship, and through Claudia, I became acquainted with her ideas and ideals, her commitment and dedication.

In spite of never having met Jackie, I am one of the many new and established students and scholars who, through the legacy she left us, testify in some small way to the enduring and ever-growing presence of a past which included the work she engaged in, the people she impressed, and the knowledge she produced. As T.S. Eliot wrote, "No poet, no artist of any art, has his [or her] complete meaning alone" (1999: 26). And this is certainly true for those of us who have been, 
and who will be, marked by Jackie's work and art. But we do not need Eliot's words to know that Jackie has an enduring presence in both current and future scholarship and activist work. Jackie revealed that she understood all too well the prevalence of the past in the present. Indeed, in my opinion, it was her unapologetic championing of this aspect of knowledge production that set her apart from other academics and which distinguished her in her field. In my favorite article of Jackie's, "Starting with the self: Reflexivity in studying women teacher's in development" (2004), I was introduced to the critical practice of reflexivity, a process which "necessarily engages the self in critical exploration of experience, perceptions and positions" (239). Reading this article for the first time, (I have read it many times since) early on in our Women, Education, and Development course, I was invited to begin with myself before embarking upon any intellectual, activist endeavor. She urged me to engage in what she described as "a constant questioning of what I am doing and why". As I was setting out to etch my own mark of knowledge, she implored me to ask: "Why? From where? Founded on what?" (2004: 233 my emphasis). She shared with me the notion that there's always a history behind what we see and how we see it, and, therefore, there is always a need for situating our observations within the context of our personal histories. What follows is my first attempt to do just that, a journal entry that I wrote shortly after I first read Jackie's "Starting with the self..." for my course with Claudia.

As a first year Master's student, my particular interest (at this moment) is education within groups-as it happens between members of that group-that acts to empower the community to resist subordination. The indigenous movement in Canada, I feel, is a particularly important example of this process taking place. The Mohawk (or Kanienkehaka) communities Kanehsatake, Kahnawake, and Akwesasne south of Montreal, have had a continued, and at times hostile, engagement with Canada. My work right now is examining how youth in this nation take up identities as political activists, the gendered dimension of this, and the teaching and learning that are inherently involved. How male and female youth engage in processes of national identity building that creates community in acts of resistance, I find of particular interest considering the matriarchal nature of the Mohawk nation, and worthy 
of research covering ideas that include women, development and education. Therefore, as a first step, adhering to the problematic but rigorous advice of Dr. Jackie Kirk "that studying the self makes a very appropriate starting point for research with women ... in development contexts" (Kirk 2004: 239), I thought it would be diligent to start with the self.

So, how do I, a white male who would like to study female engagement in acts of liberation by a racialized and marginalized group, engage in this process of reflexivity, as laid out by Jackie Kirk? It seems that otherwise the validity of the information gathered would be questionable. But then, for the same reason, does placing myself within the research not distort the data beyond value? Recognizing, as any researcher would, that the knowledge acquired is a product of the research experience, is this knowledge limited to the experience? How does it become applicable to a wider population? In other words, as I start with myself, I am faced with the question: "Is it possible to get beyond my own race, sex and gender, even as I include it in the study, to achieve some sense of insight?" As I "problematize my own identities and positions" (Kirk 2004: 239), and recognizing that with women researching women there is a shared ground, I'm questioning the insightfulness of this project. Again, what is the role of men in feminist research?

Much of the work we engage in here at McGill's MA in Education program examines the dangers of continuum thinking, whether it be cultural, economic, or in relation to knowledge production. The danger lies, as I understand it, in the disjuncture between meaning and how this meaning is represented, and the power involved in that representation. What follows is an acceptance that meaning is constructed differently depending on context—social, economic, political—and a rejection of universality (as a common application of truth). This means that widely held ideals of what counts as progress cannot be considered global but must be traced back to certain conditions and cultures, otherwise there is a real danger in mis-recognizing in our representations (Taylor 1997). Peter McLaren, in the introduction to his Critical Pedagogy and Predatory Culture: Oppositional Politics in a Postmodern World (1995) explains that the task of "[1]iving as a critical social agent means knowing how to live contingently and provisionally without the certainty of knowing the truth, yet at the same time with the courage to take a stand on issues of human suffering, domination, and oppression" (1995:15). To me, 
this statement appears to embody the research that Jackie Kirk engaged in, as she attempted in her work to "take a stand on issues".

Rushdie says that when we attempt to make sense of our world, "objectivity becomes a great dream" (1991:101). As I have understood it, Homi Bhabha in the introduction to his The Location of Culture (1994), suggests that postmodern thought as a way of understanding the nature of our world, rejects the modern hierarchal polarization of reality_black/white, good/bad, right/wrong — and acts to navigate between these ideas. Jackie Kirk's explanation of the praxis of reflexivity, that "includes a sustained attention to the position in which I place myself and am placed by others" (2004: 233), follows from the inability to separate oneself from history or context. The absolute binary divisions of researcher and researched no longer exist-nor have they ever existed. In a similar vein, because the act of research is education itself, Paulo Freire in Pedagogy of the Oppressed (2002), agrees: "[e]ducation must begin with the solution of the teacher-student contradiction, by reconciling the poles of the contradiction so that both are simultaneously teachers and students [researchers and researched]" (2002: 72). Kirk explains a way of understanding the real potential of reflexive research:

The tensions and contradictions as well as the pleasures generated by my research activities may, at times, have been frustrating. However, when probed further, these continuities and discontinuities, the smooth linkages and dissonances between periphery and center, between self and other, and between theory and practice, become sources of insights and a springboard for further investigation (Kirk 2004: 233).

I guess, in the grandest sense, the value of this investigation that I am contemplating, if at all possible, would be in the insight brought forward in attempting to bridge the race and gender divide. Because we share, in the words of Said, "overlapping communities" and "intertwined and overlapping histories" (1994: 18) perhaps the possibility exists "to see complementarity and interdependence instead of isolated, venerated, or formalized experience that excludes and forbids the hybridizing intrusions of human history" (Said 1994: 96) or as Bhabha explains in The Location of Culture (1994), perhaps we can find an "interstitial passage between fixed identification [that] opens up the pos- 
sibility of a cultural hybridity [and] that entertains difference without an assumed or imposed hierarchy" (1994: 5).

As I continue to grow and take bigger steps from these initial, somewhat naïve and idealistic first steps engaging in academia, I will nevertheless continue to heed Jackie's advice to start with myself in an attempt to "problematize my own identities and positions" (2004: 239). And, as I start with myself, I realize that my academic and activist hopes are firmly founded in the impression Jackie made upon me. In this way the past never passes. Never having met Jackie, I do not have an intimate memory of her life to offer. Instead, what I do hope to offer is a glimpse of how the memory of Jackie works on us in the present and will continue to work in the future, even among those whom she never knew.

\section{References}

Bhabha, Homi. 1994. The Location of Culture. London: Routledge.

Eliot, T. S. [1920] 1999. The Sacred Wood: Essays on Poetry and Criticism. New York: Bartleby.

Freire, Paulo. [1970] 2002. Pedagogy of the Oppressed. New York: Continuum.

Kirk, Jackie. 2004. "Starting with the Self: Reflexivity in Studying Women Teachers' Lives in Development." Pp. 231-241 in Just Who Do We Think We Are? eds. Claudia Mitchell, Sandra Weber, and Kathleen O’Reilly-Scanlon. New York: Routledge.

McLaren, Peter. 1995. Critical Pedagogy and Predatory Culture: Oppositional Politics in a Postmodern World. New York: Routledge.

Rushdie, Salman. 1991. Imaginary Homelands: Essays and Criticism 1981-1991. London: Granta Books.

Said, Edward. 1994. Culture and Imperialism. New York: Alfred A. Knopf.

Taylor, Charles. 1997. “The Politics of Recognition.” Pp. 98-131 in New Contexts of Canadian Criticism, eds. Ajay Heble, Donna Pennee, and J.R.Tim R. Struthers. Peterborough, Ontario: Broadview Press. 